Article

\title{
Family Involvement and Sustainable Family Business: Analysing Their Effects on Diversification Strategies
}

\author{
Ines Herrero \\ Business Management and Marketing, University Pablo de Olavide, Ctra. de Utrera Km. 1. Dep, \\ 41013 Sevilla, Spain; ihercha@upo.es; Tel.: +34-954-348-906
}

Received: 16 October 2017; Accepted: 9 November 2017; Published: 15 November 2017

\begin{abstract}
Recent studies have noted that traditional agency theory and risk attitudes differ when firms are small and have a family character. In this work, we provide new insights with respect to the effect that the family role and the different types of risk exert on diversification strategies. We provide a different view on the effect that the number of generations and having a family manager exert on diversification attitudes and we analyse the concept of family involvement for small family firms and the moderating role it has in the relationship between the different types of risk and diversification decisions. By using a behavioural model analysis and a set of fishing firms to test our hypotheses, our results corroborate the importance of family variables on the behaviour of small family firms and how these firms avoid risk under certain stable conditions while take riskier decisions when sustainability and survivability is menaced by unstable environments. We not only provide theoretical reasons that help to the understanding of diversification decisions of small family firms but we also draw some specific conclusions that will help fishery managers to achieve more sustainable fisheries by a better understanding of fishers behaviours.
\end{abstract}

Keywords: risk; diversification; family involvement; family firms; fisheries; fisher behaviour

\section{Introduction}

Within-business diversification, understood as when firms extend product lines or expand into new ones, has been widely researched in the strategy literature [1]. It is commonly argued that related diversification enables firms to take advantages of their resources by sharing knowledge and assets across different activities leading to economies of scale and increases in performance [1,2]. Traditionally, diversification has been seen as a way for firms to survive and be sustainable over time as it reduces risk concentration by reducing the overall variance in expected outcomes [3]. As owners of small family firms generally own most or all the shares of the family business [4], contrarily to the diversified portfolio of large firms' shareholders [5,6], they should be more prone to diversify firm's activities to spread not only the firm risk but also the risk of the family patrimony [7]. Furthermore, some authors argue additional reasons to support that small family owners are risk-averse as individuals tend to be more risk-averse when making decisions on their own than when decisions are taken in groups [7].

Paradoxically, and in contrast to previous arguments, empirical results offer mixed findings regarding diversification in family firms [8-10]. Family firms have been seen as risk averse [11]. However, some scholars argue that, while diversification may be seen as a road to avoid risk when compared to the situation when the whole business is focused on one activity [12], in small family firms, it may also bring about a high dose of risk in the sense that it requires raising additional capital and there is uncertainty about the potential success of the new activity, particularly if the manager does not have the abilities and the knowledge necessary to carry out the new activity [11]. Diversification often implies having to include outsiders and, consequently, a loss of SEW, making family firms reluctant to diversify [12]. In this sense, some authors [5,13] claim that preserving the socioemotional 
wealth (SEW), understood as the non-financial aspects that meet the family affective needs [13], such as identification of the family with the firm, family influence, etc., plays a crucial role in the strategic behaviour of family firms in such a way that preservation of SEW may lead many family firms to avoid diversification.

Arguing the former or the latter reasons, conflicting views appear in the literature on the attitudes of family firms towards corporate diversification and entrepreneurial activities [6,8-10], so that the balance between conservation and growth is still an open question [8-10]. This has been the key motivation of our work: there seems to be a gap in the literature with this respect in spite of the importance of diversification for the sustainability and survival of firms and the important contribution that family firms make to the economy [5]. Furthermore, risk attitudes within small family firms have not received much attention and the results in the literature are not conclusive $[6,9,10]$. With our study, we try to shed a light to the clarification of the variables that affect diversification in small family firms, redefining some of them and paying special attention to the different effects when compared to those assumed in the literature for large firms. In particular, we redefine some concepts such as family involvement in small firms. Up to now, little empirical and theoretical evidence has been shown to analyse the impact of family involvement on entrepreneurial behaviour or specifically on diversification [14]. In this paper, we provide some theoretical and empirical support on the influence of family employment on diversification decisions. While family employment may not be so much relevant in large firms as non-managerial family employees may not have a say in decisions and may also represent a small proportion in terms of labour, but it can be important in the case of small family firms, which are more organic and decentralized and which may allow a high dose of empowerment, particularly for family employees. We also analyse the moderating effect of other family-related influential variables on diversification attitudes, such as having a family manager or the number of generations the family has been involved in the business. Furthermore, while we provide theoretical arguments to support that family firms are risk averse, we also argue that this relationship is moderated by the influence of performance hazard and different types of risk associated to the current activities in which the firms operate. We argue that both, variability in own performance (which would be perceived as risk) or declines in own performance (which would be perceived as a "hazard signal") [12] can change family firm attitudes towards diversification. Should risk or declines persist, the risk of bankruptcy appears. Family firms would feel that their SEW is at risk and under this situation they would become more prone to diversify than none-family firms. Furthermore, we also theorised that this change of attitude towards diversification under risk is particularly strong if family involvement is high as the work and the patrimony of several family members may be at risk.

A key reason why we focused on small family firms is that they represent an important contribution to the general economy [5] while at the same time there seem to be a gap in the management literature with respect to small family firms [5].

Based on the above arguments, this study is set in the context of small family firms and tries to answer the following research questions: How do attitudes towards diversification differ between family and non-family firms? How should family involvement in small family firms be defined? How does it affect firm's diversification decisions? Does family involvement affect the moderating effect of the different types of risk? Are diversification decisions also affected by family management? We think the research questions we try to answer are important for the field of management as this type of firms is very numerous and represents a very important contribution to the economy [5], the diversification decisions may affect greatly to firm's survival and success and there seems to be a wide gap in the literature with this respect.

To answer the above research questions and test our hypothesis, we have carried out our empirical analysis in a quite homogeneous environment as all firms belong to the same industry, the fishing sector. Regarding size, both the family and non-family firms in our sample are also relatively homogeneous and all of them are subject to the same legal issues. The fishing firms in our sample constitute a good example of simple, low-structured, family firms in a homogeneous environment (as they belong to the 
same sector, same country and have similar and simple characteristics) where the effect of the variables that we intend to study can be more easily isolated. This sector has been traditionally ignored in the management literature [15]. In particular, very few studies have focused on risk or risk attitudes in the fishing industry [16] and even less have paid attention to the effect that the family character that many of these firms possess may exert on vessel's decision making. One of the few studies on risk in commercial fisheries was carried out by $[16,17]$. As their study was framed in an economy context, organizational variables such as separation of ownership and management, the effect of having family employees or having related managers were not taken into account. From our results it seems that family-related variables influence the decision making of fishing firms which is of high relevance given that family firms tend to be more compliant in respecting environmental standards than their counterparts [18] and that there are many family firms among vessels in small-scale fisheries.

Our paper is structured as follows: in Section 2, we introduce the topic, present the theory underlying our study and settle the key hypotheses. We also present the materials and the methods used, which is followed by a description of the data and the variables used. Then, in Section 3, we present the results, and finally make a discussion and draw some conclusions.

\section{Materials and Methods}

\subsection{Diversification in Small Family Firms}

Family firms have been proved to behave differently to non-family firms $[19,20]$ though the differences are not clear cut in the literature. In particular, there are conflicting views regarding the attitudes towards risk or towards diversification when compared to their counterpart non-family firms $[5,13]$. While there are a number of reasons that suggest that family firms may see diversification as a way to reduce risk concentration on a single activity and to protect the family patrimony [4], the literature offer other reasons that explain why family firms may not be so keen on diversification [21]. In the following, we support that the arguments that maintain that family firms are reluctant to diversify are of particular relevance in the case of small firms. We have classified these reasons into four: economic reasons, work-environment reasons, informational reasons and socioemotional reasons.

Firstly, we can find some economic factors that make family firms reluctant to diversify. According to [22], there is a means-end relationship between entrepreneurship activities and family business. Entrepreneurship represents a mean for the family firm to achieve the end of sustainability and long-term survival [22]. While diversification may be seen as a road to avoid risk when compared to the situation when the whole business is focused on one activity [12], many entrepreneurial activities fail or take several years to be profitable; therefore it may also bring about a high dose of risk in the sense that it requires raising additional capital and there is uncertainty about the potential success of the new activity, particularly if the manager does not have the abilities and the knowledge necessary to carry out the new activity. Raising additional capital is particularly difficult for small firms, who can see that it is not only the owner who has most of his patrimony involved in just one business but also that the economic situation of a few family members [21], linked to the business either through employment or ownership, may also be closely related to the business' success [5]. Furthermore, some scholars [23] argue that many family owners are satisfied with earning enough for a living and growth past that level is highly unlikely.

Secondly, with respect to the work environment reasons, some authors maintain [23] that diversification is even more unlikely if the non-growing strategy is related to a certain lifestyle (informal, anti-bureaucratic, loose, individualistic, etc.) typical of small firms, that would be lost in the case of growing. In the same line, Daily and Dollinger [24] maintain that a professional managed firm is more likely to be larger than a family firm because, among other reasons, managing growth in a family firm is more complicated and their managers are not so growth-oriented. Other authors, such as Claver et al. [25], provide a similar argument by maintaining that family firms often sacrifice a certain degree of profitability to ensure that family control is preserved. Therefore, in order to protect firm's 
culture and autonomy, family owners may become too strategically conservative, thereby minimizing entrepreneurial behaviours [14].

Thirdly, the literature offers some informational reasons to believe that family firms may be more reluctant to diversify. Indeed, in small firms owner-managers may lack enough knowledge or information needed to diversify when compared to bigger firms [23]. To take the decision to change and get involved in a new activity, these firms may need to hire experts from outside and to rely on the information these outsiders provide. Some scholars [26] argue that executive entrenchment in family firms makes these executives be not fully competent and, consequently, these firms take a conservative position not getting involved in entrepreneurial activities. Furthermore, family firms are said to become more conservative over time [27]. Owners of small family firms may be more reluctant to accept outsiders because family members know each other, as they have grown together, and they have a more unified outlook [28] and including these outsiders may disturb the family business. In a similar vein, Galve and Salas [29] provide empirical evidence to maintain that family firms are less prone to diversify arguing that diversification may imply the need of some experts and family firms are more reluctance to take into account outsiders' opinions. Furthermore, there are also some costs associated with getting information, and they are assumed to be inversely related to firm size [23], i.e. for small family firms, it would be more costly to obtain the information needed to engage in a new activity.

Finally, further to the informational reasons and the associated costs that managers may argue, the most important factor seem to be the emotional level [23]. Leaving some important decisions in the hands of outsiders implies losing part of the family control and autonomy, losing prestige and losing what some authors [30] have defined as the socioemotional wealth (SEW). Some scholars (Gomez Mejía et al., 2007; Gomez Mejía et al., 2010) have shown how protecting SEW influences the diversification strategy followed by the firm and its attitudes towards risk. Therefore, as diversification and outsiders are assumed [12,30] to imply some loss of socioemotional wealth (SEW), many family firms are more interested in keeping their socioemotional wealth (SEW) than in growing [13].

In summary, we argue that the desire to keep work environment, family control and autonomy, preserving the SEW or the endowment effect act as psychological barriers to entrepreneurial behaviour in most small firms [23]. Additionally, if most of the patrimony of the family is involved in the firm, owners will be reluctant to risk more capital [31]. Consequently, we argue that, when dealing with decisions on diversification, small family firms are more interested in preserving the economic and socioemotional wealth of the family business than in diversification as suggested by [12] which leads us to the following hypothesis:

Hypothesis $\mathbf{1}\left(\mathbf{H}_{\mathbf{1}}\right)$. Small family firms are less prone to engage in diversification than small non-family firms.

\subsection{Diversification and Family Involvement}

Most family firm literature has been focused on the effect that family ownership or family founders $[8,20]$ exert on different issues such as performance, risk attitudes, firm succession, the strategy followed by the firm or corporate governance. With few exceptions [32,33], the contribution of the literature on the effect of family employees on these issues is very scarce. However, family employment has been proved to be influential on business' performance and attitudes towards risk [34] and in particular among small firms.

Some scholars $[13,26,35]$ have argued that the higher the percentage of family ownership, the less likely the business will get involved in diversification or will present risky strategic behaviours. Following the same logic, in small firms where the ownership is usually concentrated in very few hands [35], family employment (apart from shareholders or managers) may play a similar role, given that the survival of the family members working for the business is linked to the firm's success. A failure of the small family business implies that the household economy of all family employees 
will be affected [5] (Gomez-Mejia et al., 2001). This puts these firms at a disadvantage in terms of risk bearing and consequently they would be less keen on entrepreneurial activities.

As we stated before, many scholars $[13,26,35]$ use a behavioural perspective to support that it is not only for economic reasons but also to preserve socioemotional wealth why these firms are not keen to diversify. Gomez-Mejía et al. [13] argue that the higher the family role, the higher the socioemotional wealth. These authors suggest that the family's attachment to the organization is highest when the firms is owned and managed by the founding family and that it tends to weaken over the following generations. Following recent literature $[13,36]$, we will use here a contingency approach to maintain that risk attitudes and strategic behaviours change with the framing of problems. Considering that we are dealing with small firms, family employees represent a substantial percentage of the employment and, consequently, they represent a relevant issue concerning the family role [33]. The literature [13,37] defines the family attachment to an organization as the number of generations it has belonged to the same family. However, we have considered the family role not only in terms of the business stage with respect to the number of generations in the family business (as in $[13,37,38]$ ) but also in terms of number of family employees working in the family business. Further to considering this variable as a dichotomous variable (having/not having family employees) (as in [33]), we have considered a continuous stage of family employment (given by number of family employees) as suggested by Astrachan et al. [39] who used three subscales: power, experience and culture (F-PEC scale). The experience scale is a continuous scale given by the number of generations in the family firm and the number of family employees involved in the business. Therefore, we argue that in the context of small firms the family attachment to the organization is related to both issues: family employment and number of generations in the family business.

As we mentioned before, family attachment to the organization is assumed to be highest during the first generation in the business $[13,37,38]$, when it is managed by the founding family. When family firms evolve into large corporations, subsequent generations may not feel such strong identification with the family business. However, we argue that, when family firms do not evolve into bigger firms, the higher the number of generations in the small family firm, the higher the family attachment to the business. This argument is in line with Gray [23] who maintains that it is widely accepted in the small firm literature that, apart from the start-up phase, most small firms are more concerned about survival than growth and are not especially entrepreneurial once they feel that they are established. When a small family firm has been running for generations within family hands and it keeps under the family control and autonomy, the identification family and business is stronger. Often the identification family-business is so strong that it is difficult to draw the line between the family and the business [20,33]. Descendants may feel they disappoint their ancestors if they do not keep on with the family business. Owners feel they need to preserve the family tradition of running the business that was kept for generations. Consequently, these firms will be keener on protecting the SEW and the family business that was preserved over generations. We need to clarify that this reasoning may not be valid in other contexts such as for large firms where family members do not feel such strong identification between family and business.

On the other side, we claim that the founding family is expected to be composed of very entrepreneurial individuals, whereas this characteristic may be diminished in subsequent generations as descendants are born in the safety atmosphere of the family business. Although this idea contrasts with the traditional view, it is in line with some other results that can be found in the literature. For example, Claver et al. [25] proved that the first generation in the family business perceives less risk about their international activity than subsequent generations and Sharma et al., [40] maintain that the risk of losing the family wealth created over time prevents family firms to get involved in entrepreneurial activities. Moreover, psychological costs exist if entrepreneurial activities lead the family firm to a failure as there is interdependence among family members within and across generations [41]. Descendants usually grow under the cover of a safe job and often with a 
management position guaranteed, which may make them more reluctant to change and to have entrepreneurial incentives.

Again, this logic cannot be applied to family firms that got larger in their initial stages and that in subsequent generations the identification of the family and the business is not so strong. Bigger family firms probably have wider knowledge and more financial resources to start new activities but we argue that the reverse occurs in small businesses. According to this, we expect that over the generations, small family firms will become less entrepreneurial, keener on keeping the socioemotional wealth that was preserved over several generations and consequently less keen on diversifying their activities.

On the contrary, with respect to the other aspect of family involvement, it seems reasonable to expect that the higher the level of family employment the higher the family's attachment to the organization [37]. In a similar vein, Miller et al. and Le-Breton Miller et al. [26,31] suggest that the higher, the family role in the business' ownership, the lower probability that they diversify. This is particularly relevant in small firms as strong ties and SEW wealth are reduced as organizations evolve towards big companies $[33,42]$. Therefore, the higher the family role (in particular, in terms of family employees) the higher their level of socioemotional wealth and the higher the interest in retaining family control which implies lower involvement in diversification activities [13]. All the preceding arguments lead us to the following hypotheses:

Hypothesis $\mathbf{2}\left(\mathbf{H}_{\mathbf{2}}\right)$. The stronger the family role in terms of the number of family employees, the more likely the firm is to protect its socioemotional wealth and the less prone they are to get involved in diversification activities.

Hypothesis $\mathbf{3}\left(\mathbf{H}_{\mathbf{3}}\right)$. The stronger the family role in terms of the number of generations, the more likely the firm is to protect its socioemotional wealth and the less prone they are to get involved in diversification activities.

\subsection{Diversification and Family Managers}

According to the Agency Theory, the principal and the agent keep different attitudes towards risk $[43,44]$. These different attitudes lead the principal and the agents to prefer different actions provoking what is known as the risk-sharing problem [3]. While, in its origins, Agency Theory maintained some general rules regarding the attitude of the principal and the agents towards risk, more recent views [30] suggest that the attitude towards risk change with the framing of problems. Therefore, whether the firms are own-managed or if they are managed by a family-related manager can also lead to different strategic behaviours as suggested by [31]. We go further than some of the previous studies, by considering whether management is held by the owner or by related managers.

The relationship between ownership and family operational involvement in the business is not clear in the family firm literature [45], as with few exceptions [5], most papers in the literature do not distinguish among the differing effects of family ownership and family management. Agency theory has traditionally viewed the agent as risk-adverse as his fate was highly involved with the success of the firm and, consequently, he may adopt a low risk/low return strategy [28]. However, some authors maintain that, in family firms, the reverse occurs [5]. These authors suggest that family managers are less likely to be penalised for evidence of high risk decisions because of family ties. When a person perceives greater benevolence towards him/herself from another individual, then he/she will be happier to bear a greater dose of risk [28]. Family managers may feel this way and, consequently, they do not have the feeling that their position is in danger because of taking high risk decisions, which may lead them to be more prone to risk. On the other hand, in the case of a successful decision (even if it is a highly risk decision), the manager's performance would be appreciated by the owner, which would be reinforced by the successful effect on the family as a whole. Therefore, managers may be less risk-adverse than family owners and we expect that:

Hypothesis $\mathbf{4}\left(\mathbf{H}_{4}\right)$. Family-related managers are more likely to diversify than owner-managers. 


\subsection{Diversification and Risk}

On the one hand, diversification may represent less economic risk in the sense that it avoids the risk of concentrating the whole business to one activity [12]. However, on the other hand, diversification implies a higher risk in the sense that it requires raising additional capital and there is uncertainty about the potential success of the new activity, particularly if the manager does not have the abilities and the knowledge necessary to carry out the new activity. This uncertainty is closely related to the potential variability in the current business and in the new activity. One of the most common risks that a manager faces results from the variability in firm's performance [46] and, in fact, family firms are not risk averse but loss averse [11]. Some authors [47] have classified business risk into two components: systematic risk (or beta) defined as the variability in performance in the overall industry and unsystematic risk (or epsilon) defined as the variation in a firm's performance that cannot be attributed to the industry but to the firm itself.

Recent studies [12] support that family firms generally get less involved in diversification than non-family firms. However, family firms do not show an "irrational" loss or risk aversion. Their conservative strategies may indicate a "prudent financial planning" to achieve family firm goals [11]. Consequently, as both types of risk increase (in the current business), family firms would feel that their SEW is at risk and under this situation they are more prone to diversify than none-family firms. This situation is related to the Behavioural Agency Model (BAM) of managerial risk taking and the "endowment effect" [23] or the concept of "loss aversion", understood as "avoidance of loss, even if this means accepting higher risk" [30]. According to this, family firms would be not risk averse, but loss-averse [11] as they would be more sensitive to losing wealth (and in particular SEW) than to increasing wealth. The literature $[35,48]$ has found that the higher the family involvement in the firm's ownership the higher the risk aversion. Following a similar reasoning, we give one step forward in the family firm literature by arguing that in small family firms the higher the family role in terms of family employment, the stronger the above relationship. We maintain that the higher the family role, the higher the family social capital and SEW and the higher the importance of preserving it.

Therefore, as the systematic and unsystematic risks of current business increase, family firms would perceive that their SEW would be more at risk and they will be keener to engage in diversification. In accordance to the previous arguments, the higher is the family role in the business, the stronger is the relationship between risk and diversification in family firms. Thus:

Hypothesis $\mathbf{5}\left(\mathbf{H}_{5}\right)$. As the systematic risk (beta risk) of current activity increases, the higher is the family role, the more likely are family firms to engage in diversification.

Hypothesis $\mathbf{6}\left(\mathbf{H}_{\mathbf{6}}\right)$. As the unsystematic risk (epsilon risk) increases, the higher is the family role, the more likely are family firms to engage in diversification.

\subsection{Diversification and Performance Hazard}

Further to analysing risk when dealing with diversification, firms' perception about their own performance may also play a crucial role in their decision-making. Firms may have a performance target but this may be difficult to guess, even for them. However, the literature has suggested that firms are sensitive to declining performance situations [12]. Therefore, the target level should be set on relative terms rather than on absolute values. Often firms are assumed to set their targets depending on the average performance in their respective industries or on their own historical performance [13]. Some previous studies $[49,50]$ maintain that when organizations approach a failure situation, their goals evolve from an aspiration level towards a survival level which affects their attitudes towards risk. If firm performance keeps below their target level and its distance to that target increases, firm's attitudes may change. Declines in own performance may be perceived as a "hazard signal" [12]. Should declines persist, the risk of bankrupt appears. To prevent this, firms would diversify. Consequently, family firms whose performance is below a target level tend to diversify more likely than non-family firms [12]. 
We assume that in small firms a similar reasoning applies. Furthermore, small family firms have three additional reasons to avoid the probability of failure when compared to larger non-family firms. On the one hand, family owners of small firms often have most of their capital concentrated in the family business. In the case of failure, they would lose most of their personal capital. Secondly, small family firms most commonly have several family employees. Consequently, business failure would affect not only owners but also family employees' income. Therefore, family firms would be keener to accept diversification if failure represents a real menace. The third reason is not economic but again linked to the socioemotional approach [12]. If the firm does not survive, the risk that the SEW disappears completely becomes higher [12]. Put simply, despite their being reluctant to diversify, when firms' performance keeps declining and the risk of failure increases, family firms would be keener to diversify than non-family businesses in order to survive. In a way, the risk of failure becomes an incentive to diversify [50]. All previous arguments lead us to the following hypothesis:

Hypothesis $\left.7 \mathbf{~}_{\mathbf{7}}\right)$. Family firms are more likely than non-family firms to engage in diversification as firm performance hazard increases. This relationship is stronger the higher the family role.

\subsection{Data}

Our application was on the fishing sector. This sector has many peculiarities and with few exceptions [15], hardly any management studies have analysed it. We have focused our assumptions on the context of small firms. This is the case of many firms in the fishing industry. Many fleets are composed of small enterprises, most of which are family-owned and family managed. Their structure is very simple, consisting on the owner, the skipper (acting as a manager) and the fishermen. We used a behavioural model to study our sample and test our hypotheses.

We have analysed the whole set of fishing firms that operate in a specific fishery. The fleet is composed of small firms (vessels), many of which are family-owned. Nearly $64 \%$ of the vessels have family members on board. This is a profitable fishery. The target species is a high-value species. The firms in this fleet are characterised by being very simple and basic in their structure and organization, which is the context in which we focus our study. Some ship-owners are the skippers of their own vessels whereas others do not go on board either because they are too old, because they simply act as investors or rarely because they have more than one vessel. If this is the case, the ship-owner delegates the management of his firm to an agent (one of the crew members) who is designed as the skipper. In general, if there are family members on board, the skipper is chosen among them.

During certain months of the year, some of the vessels operate in an alternative fishery. If this is the case, they need to buy new fishing gear and their new competitors are the vessels of the alternative fishery. Clients are also different and they commercialize the fish in a different auction. In the fishing industry, diversification refers to the fact of operating in a portfolio of alternative fisheries (see for example [16,51,52]). Note that, in fisheries, alternating in different fisheries is a way of related diversification as it allows fishing firms to expand their products range and to expand their markets while at the same time keep using the same type of resources and hot leaving the fishing sector. For this reason, in the fishing literature $[16,51,52]$ this has been considered a measure of related diversification. Some authors [53] classify fishermen between those that diversify (generalist) and those that do not (specialist). This is an alternative fishery which generally last for about 5-6 months per year. While the alternative fishery is of higher profitability, it brings about higher levels of economic and physical risk. The law does not allow them to operate in both fisheries during the same day, but each day they can take the decision to operate in one or another fishery so that over the month they can take the option to dedicate a certain proportion of trips dedicated to each species. The revenues of the alternative fishery present a higher variability from one day to another and this fishing practice involves more risk regarding physical accidents. On the contrary, the main fishery offers less daily benefits but they are more stable over time. Each of the two alternatives present different levels of risk and fishermen can manage daily this risk. A risk-adverse behaviour would imply the selection of a fishery with 
more stable revenues and diversification and having to invest in new fishing gears would not be an attractive option. Therefore, if a skipper is risk-adverse, his decision would be not to operate in the alternative fishery, but operating in the main fishery all year round. However, operating in a given fishery requires a certain amount of expertise which can only be provided by time spent at sea. If a family firm suffers performance variability and performance declines and they perceive that the family firm and/or family patrimony is at risk, we expect that that firm may feel that if they keep operating in the same fishery and do not get expertise in the alternative fishery, if/when the current fishery becomes heavily over exploited they may not be able to react on time. Consequently, even if family firms are reluctant to diversify, they would be more prone to diversify to protect the family firm if they experience performance declines or see their revenues at risk. Protecting the family firm takes even more relevance the higher the family involvement, as there is more family members to protect.

We used three different datasets. First, we got information from direct interviews with ship-owners. From these surveys, we got information on whether each vessel alternates the main fishery with the alternative fishery, coincidence of the skipper and ship-owner in the same identity, if they are family related, number of family members on board and the number of generations within the same family working in the fishery sector. Our second dataset consisted of daily value of the landings and species by boat over a period of six years. We classified this information and discarded the months for which the alternative activity could not be carried out. Then, we distinguished the trips dedicated to the main species or to the alternative fishery. We aggregated this information by month and got the percentage of trips each of the vessels went to one or another fishery each month under analysis. Our third dataset came from the official census, from which we got the physical variables of the vessels. We matched the three datasets and removed observations with missing data in each of the variables which resulted in a sample of 73 fishing firms (vessels). Therefore, our dataset included basically the whole fleet.

\subsection{Variables}

\subsubsection{Dependent Variable}

Diversification is measured in a wide variety of ways in the management literature. We considered a dummy variable for each day that was equal to 1 if the vessel operates in the alternative fishery on that specific fishing trip (implying its skipper is prone to take risky decisions) and 0 otherwise (implying the skipper is risk-adverse). To account for the firm's involvement in diversification, we aggregated data monthly and considered the percentage of trips that the firm dedicated to the alternative activity. If a firm does not diversify in a specific month, then this percentage is zero for that month.

\subsubsection{Independent Variables}

Family firm. Whereas family firms are the oldest form of firms, paradoxically, there is no consensus regarding the definition of what a family firm is. In our study, we have considered a firm to be of family-type when the manager and/or some of the employees have familial ties to the owner [54]. This variable is then represented by a dummy variable equal to 1 in the case of family firm and equal to zero otherwise. While this variable dichotomized the term family firm, in what follows we consider other continuous variables that describe the family involvement.

Family involvement. We considered two levels of family involvement. The first level was given by the number of generations (level 1) the family have been involved in the family business. The second level was the number of family employees (level 2) working for the firm, which represents the "continuous" aspect of the family character.

Family manager. This variable is given by a dummy variable equal to 1 in the case of family manager and equal to 0 otherwise.

Systematic risk of the business (beta). This variable is assumed to control for variability in performance in the overall industry. We measured performance as the Value Per Unit of Effort (VPUE), which is the most common performance measure in the fishing activity. For each period, we considered the 
standard deviation in the performance of the average revenues per day. Note that this variable is not a characteristic dependent on the firm's but an attribute of one of the choices (the traditional fishery).

Unsystematic risk of the business (epsilon). This variable is assumed to control for variability in performance due to the firm itself. Effectively, changes in income over time affects the satisfaction with income [55] and may drive fishers decisions. We considered the standard deviation in the firm's performance of the average revenues per day.

Performance hazard. This variable should represent the firm's perception about their own performance. We assume that the target level is not set on absolute values but with respect to the firms' previous performance or with respect to the average performance in the industry. Declines in own performance may be perceived as a "hazard signal" [12]. We considered firms to be sensitive to their own performance history (performance hazard). To measure this variable we considered the (natural logarithm of the) ratio of their own performance and their own performance in the year previous to our analysis. If this ratio is greater than one, it means that the firm's performance is improving, whereas, if it is lower than one, it would be declining (in logs the measure takes negative values for declining performance).

\subsubsection{Control Variables}

Firm's capacity. According to fishermen, for practical reasons, it seems that bigger vessels have a greater tendency to go to the alternative fishery. Therefore, we included a measure of physical capacity of the firm as a control variable. This variable was given by two indicators: the engine power of the vessel (measured in horse power, HP) as the more powerful the vessel is the higher the capacity and by the volume of the vessels (measured in gross registered tonnes, GRT).

Firm's size. This variable was given by the number of crew members. On some models, this variable was omitted to avoid multicollinearity problems, as it was highly correlated to some variables.

Skippers' age. More experienced skippers are more likely to diversify than less experienced ones. As all the skippers had been working in the fishery officially or unofficially since their youth, we used their age to account for experience.

\subsection{Methods}

The model we have used is what is known as a behavioural model [56,57]. This is a more general model than the multinomial logit model. The multinomial logit model assumes that the utility of a choice-maker are modelled in terms of characteristics of the individuals. On the contrary, conditional models assume that utilities depend on the characteristics of the alternatives rather than attributes of the individuals. Our model combined the multinomial and conditional logit formulations, so that the underlying utilities depend on characteristics of the individuals as well as attributes of the choices, or even variables defined for combinations of individuals and choices. In these models a choice is defined as the decision made by the "choice-maker". In our case study, the choice maker $(i)$ is a fishing vessel. The choice is the daily selection of the fishing trip (in our case, either the main fishery or the alternative fishery). Behavioural models estimate the probability that the choice-maker $i$ will select a certain choice $j, p_{i j}$. This is a repeated discrete choice. In a binary situation, the odds that a fishing firm will make the choice $\mathrm{j}$ are defined as: $p_{i j} /\left(1-p_{i j}\right)$. The odds are the number of times the choice will be made relative to the number of times the choice will not be made. Rather than using probabilities in the model formulation, we will make use of the natural logarithms of the odds (logit): $Z_{j}=\operatorname{logit}\left(p_{i j}\right)=$ $\ln \left[p_{i j} /\left(1-p_{i j}\right)\right]$. Note that: $0 \leq p_{i j} \leq 1,0 \leq\left[p_{i j} /\left(1-p_{i j}\right)\right]<+\infty<$ and $-\infty \leq \operatorname{logit}<+\infty$.

The inverse logit becomes:

$$
p_{i j}=\frac{e^{Z_{i j}}}{1+e^{Z_{i j}}}
$$

and it is called the logistic curve.

The probability of choosing an alternative depends on the utility that each firm gives to it: $p_{\text {choice }}^{\text {firm }}(t)=F^{f i r m}(t, U(t))$, where $U(t)$ is a vector of utilities: $U(t)=\left(U_{1}(t), U_{2}(t), \ldots, U_{m}(t)\right) . U_{j}(t)$ is a 
measure of the choice-makers' welfare for taking decision $j$. The higher the utility of a choice, the higher is the probability that the choice will be taken. $U$ is a stochastic variable, $U_{\text {choice }}(t)=Z_{\text {choice }}(t)+\varepsilon(t)$, where $\varepsilon$ is a stochastic variable with mean zero and follows a Gumbel distribution. Thus, $Z$ can be interpreted as the average value of $U$, or as a deterministic utility. If $\varepsilon=0$, all trips would take the decision with highest utility. Mathematically, it can be written as: $p_{j}=\operatorname{Pr}\left\{U_{j} \geq \operatorname{Max} x_{k \in C} U_{k}\right\}$, where $C$ is the set of all feasible choices:

$$
p_{\text {choice }}(t)=\frac{e^{U_{\text {choice }}(t)}}{\sum_{j=1}^{m} e^{U_{\text {choice }, j}(t)}}
$$

Combining this model with the utility model, we obtain the Random Utility Model (RUM), in which the utility is treated as a "random variable". The specification of the model is reduced to the specification of the utility function:

$$
U_{\text {firm,choice }}(t)=Z_{\text {firm,choice }}(t)+\varepsilon_{\text {firm, choice }}(t)
$$

Explanatory variables, $Z$, can be of two different types: characteristics of the decision makers (such as firm's size, being a family firm, etc.) so that they vary across the choice-makers but not across the choices and attributes of the choice (such as the risk it involves). When a choice is made, the model predicts the joint effect of an attribute and the individual characteristic of the choice-maker. The deterministic part of the General logit model [58] in this case can be expressed as follows:

$$
Z_{t, \text { firm,choice }}=\sum_{r=1(\text { characteristics })}^{R} \beta_{t, \text { choice }, r} \cdot X_{t, f \text { irm }, r}+\sum_{s=1(\text { attributes })}^{S} \gamma_{t, \text { firm }, s} \cdot W_{t, \text { choice }, s}
$$

In our case study, the firm's choice consists of selecting between two fisheries: not to diversify (and keep operating in the traditional main fishery) and to diversify (that is, operating also in the alternative fishery). The mathematical model used is:

$$
Z_{t, \text { firm, choice }}=\sum_{r=1(\text { characteristics })}^{R} \beta_{t, \text { choice }, r} \cdot X_{t, f \text { irm }, r}+\sum_{s=1(\text { attributes })}^{S} \gamma_{t, \text { firm }, s} \cdot W_{t, \text { choice }, s}
$$

\section{Results}

The descriptive statistics can be found in Table 1 . The average capacity of the vessels in the sample was 6.22 GRT with an average engine of $125.84 \mathrm{HP}$. The average skipper is around 43 years old. On average, there are two family members in the firms of our sample; this average goes up to 3.11 if we exclude nonfamily firms from the sample, ranging from two to five. Approximately 1.6 generations of the family are involved in the family business.

When analysing the reasons that explain diversification attitudes, we could see that some of our hypotheses are supported by the results (Table 2). Hypothesis 1 is only partially supported as the coefficient associated to family firm (Table 2) is negative (or the exponential value less than 1) though it is only significant in only some of the models (significance has been tested through the Wald test, which is the analogous to the t-test of the standard regression analysis). This result implies that family firms are less keen to diversify when compared to non-family firms, though the results are not very robust. 
Table 1. Means, standard errors and correlations.

\begin{tabular}{|c|c|c|c|c|c|c|c|c|c|c|c|c|c|c|}
\hline & Variable & Mean & St Deviat. & 1 & 2 & 3 & 4 & 5 & 6 & 7 & 8 & 9 & 10 & 11 \\
\hline 1 & Diversification & 0.202 & 0.356 & 1 & & & & & & & & & & \\
\hline 2 & Firm capacity (GRT) & 6.228 & 2.859 & $0.333 * *$ & 1 & & & & & & & & & \\
\hline 3 & Firm capacity $(H P)$ & 125.841 & 75.386 & $0.289 * *$ & $0.633^{* *}$ & 1 & & & & & & & & \\
\hline 4 & Skipper's age & 43.476 & 11.150 & $0.052^{+}$ & $-0.119 * *$ & $-0.132 * *$ & 1 & & & & & & & \\
\hline 5 & Fam Employees $(F E)^{(1)}$ & 1.059 & 1.435 & 0.027 & $0.101 * *$ & -0.015 & $-0.104 * *$ & 1 & & & & & & \\
\hline 6 & Fam Firm & 0.501 & 0.500 & $-0.053^{+}$ & -0.016 & $-0.055^{*}$ & -0.008 & $0.737^{* *}$ & 1 & & & & & \\
\hline 7 & Beta risk & 363.229 & 102.692 & $0.058 *$ & 0.015 & 0.009 & 0.003 & -0.007 & -0.001 & 1 & & & & \\
\hline 8 & Perf. hazard & -0.055 & 0.185 & $-0.081^{* *}$ & -0.021 & -0.008 & 0.040 & $0.165^{* *}$ & 0.012 & -0.002 & 1 & & & \\
\hline 9 & Epsilon risk & 317.662 & 119.199 & $0.115^{* *}$ & $0.369^{* *}$ & $0.186^{* *}$ & $-0.110 * *$ & $-0.060 *$ & 0.036 & 0.041 & $-0.262 * *$ & 1 & & \\
\hline 10 & Generations & 1.490 & 0.796 & -0.027 & $0.176 * *$ & 0.007 & $-0.150 * *$ & $0.107^{* *}$ & $0.161 * *$ & -0.008 & $0.096^{* *}$ & 0.030 & 1 & \\
\hline 11 & Family manager & 0.398 & 0.490 & $0.065^{*}$ & $0.189 * *$ & $0.100 * *$ & $0.117 * *$ & 0.019 & $0.118^{* *}$ & 0.034 & 0.046 & $0.461 * *$ & 0.001 & 1 \\
\hline
\end{tabular}

** Significant at $0.01 ;{ }^{*}$ Significant at $0.05 ;{ }^{\dagger}$ Significant at $0.10 .{ }^{(1)}$ This refers to the number of employees related to the owner.

Table 2. Results of the general multinomial regression.

\begin{tabular}{|c|c|c|c|c|c|c|c|c|c|c|c|c|c|c|c|c|c|c|c|c|c|}
\hline \multirow{2}{*}{ Variable } & \multicolumn{3}{|c|}{ Model 1} & \multicolumn{3}{|c|}{ Model 2} & \multicolumn{3}{|c|}{ Model 3} & \multicolumn{3}{|c|}{ Model 4} & \multicolumn{3}{|c|}{ Model 5} & \multicolumn{3}{|c|}{ Model 6} & \multicolumn{3}{|c|}{ Model 7} \\
\hline & Coeff & St Err & & Coeff & St Err & & Coeff & St Err & & Coeff & St Err & & Coeff & St Err & & Coeff & St Err & & Coeff & St Err & \\
\hline Constant & -4.684 & 0.582 & $* * *$ & -4.783 & 0.589 & $* * *$ & -4.403 & 0.610 & $* * *$ & -4.622 & 0.599 & $* * *$ & -4.804 & 0.619 & $* * *$ & -4.793 & 0.592 & $* * *$ & -4.902 & 0.599 & $* * *$ \\
\hline Firm capacity & 0.221 & 0.033 & $* * *$ & 0.208 & 0.034 & $* * *$ & 0.235 & 0.035 & $* * *$ & 0.220 & 0.033 & $* * *$ & 0.208 & 0.034 & $* * *$ & 0.228 & 0.036 & $* * *$ & 0.210 & 0.034 & $* * *$ \\
\hline Vessels power & 0.003 & 0.001 & $* * *$ & 0.004 & 0.001 & $* * *$ & 0.003 & 0.001 & $* * *$ & 0.003 & 0.001 & $* * *$ & 0.004 & 0.001 & $* *$ & 0.003 & 0.001 & $* *$ & 0.004 & 0.001 & $* *$ \\
\hline Manager age & 0.020 & 0.007 & ** & 0.022 & 0.008 & $* *$ & 0.020 & 0.008 & $* *$ & 0.019 & 0.008 & $* *$ & 0.022 & 0.008 & ** & 0.021 & 0.008 & $* *$ & 0.025 & 0.008 & ** \\
\hline Beta risk & 0.001 & 0.001 & t & 0.001 & 0.001 & + & 0.001 & 0.001 & $* *$ & 0.001 & 0.001 & * & 0.001 & 0.001 & & 0.001 & 0.001 & & 0.001 & 0.001 & \\
\hline Perf. hazard & -0.001 & 0.001 & t & -0.001 & 0.001 & + & -0.001 & 0.001 & + & -0.001 & 0.001 & & -0.001 & 0.001 & t & -1.603 & 0.367 & $* * *$ & -0.001 & 0.001 & $* * *$ \\
\hline Epsilon risk & 0.000 & 0.000 & & 0.000 & 0.000 & & 0.000 & 0.001 & & 0.000 & 0.001 & & 0.000 & 0.000 & & 0.000 & 0.001 & & 0.000 & 0.001 & \\
\hline Fam Firm & -0.179 & 0.150 & & -0.438 & 0.229 & t & -0.318 & 0.232 & & -0.192 & 0.153 & & -0.439 & 0.229 & + & -0.111 & 0.245 & & -0.580 & 0.239 & ** \\
\hline Fam.Employees (FE) & & & & 0.122 & 0.080 & & 0.093 & 0.079 & & & & & 0.142 & 0.194 & & -0.026 & 0.089 & & -0.030 & 0.106 & \\
\hline FE*Beta risk & & & & & & & & & & & & & 0.000 & 0.000 & & & & & & & \\
\hline FE*Perf.Hazard & & & & & & & & & & & & & & & & 1.602 & 0.367 & $* * *$ & & & \\
\hline$F E^{*}$ Epsilon & & & & & & & & & & & & & & & & & & & 0.001 & 0.000 & * \\
\hline Generations & & & & & & & -0.245 & 0.097 & * & & & & & & & & & & & & \\
\hline Family manager & & & & & & & & & & 0.068 & 0.162 & & & & & & & & & & \\
\hline Log likelihood & -598.385 & & & -597.218 & & & -594.035 & & & -598.296 & & & -597.212 & & & -587.418 & & & -594.955 & & \\
\hline Bayes Info Criterion & 1247.183 & & & 1252.051 & & & 1252.887 & & & 1254.208 & & & 1259.241 & & & 1239.653 & & & 1254.727 & & \\
\hline Pseudo R-squared & 0.721 & & & 0.722 & & & 0.723 & & & 0.721 & & & 0.722 & & & 0.726 & & & 0.723 & & \\
\hline
\end{tabular}

${ }^{* * *}$ Significant at $0.00 ; * *$ Significant at $0.01 ; *$ Significant at $0.05 ;{ }^{\dagger}$ Significant at 0.10 . 
While Hypothesis 2 is not supported due to the non-significant coefficient associated to the number of family employees in the firm (Model 2 in Table 2) and the results of the likelihood ratio test, the number of family employees seems to exert an indirect role when its interaction with the different types of risks are included in the analysis, suggesting that managers of family firms are particularly adverse to diversification when the family involvement in terms of family employees is high. On the contrary, the likelihood ratio test when comparing the log-likelihood of Model 3 and Model 2 suggest that the coefficient of family involvement in terms of the number of generations in the family business is highly significant. Furthermore, the associated coefficient appears significant and negative (Model 3), providing support to Hypothesis 3. On the other side, Hypothesis 4 is not supported as the coefficient associated to the variable family-related manager is not significant. According to this, having a family-related manager would not affect the diversification decisions of family firms.

In Model 7, we can see that the interaction effect of the unsystematic risk and family employees is positive and significant. We have plotted this interaction to analyse more in depth this effect (Figure 1), where the high (low) values of a variable have been assumed as the mean plus (minus) one standard deviation. We can observe that while diversification is low regardless unsystematic risk for the case of low number of family employees, when the risk is high, the higher the family role, the more likely it is that family firms diversify (Figure 1), providing support to Hypothesis 6.

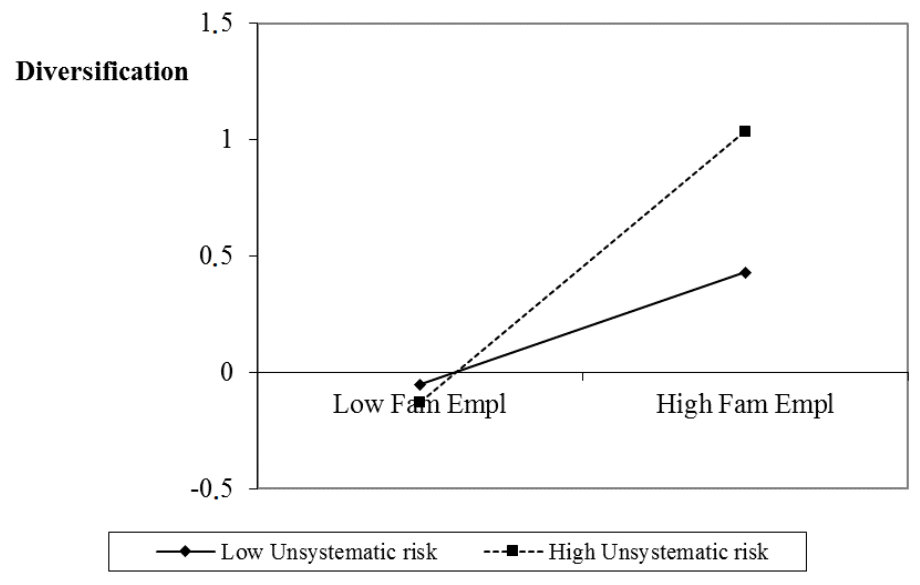

Figure 1. Interaction effect unsystematic risk-family employees.

We can observe that the interaction effect of the systematic risk and family employees is non-significant (Model 5), and, consequently, Hypothesis 5 is not supported, suggesting that firms' decisions are affected by the risk they perceived in their firms, but are not affected by the variability in the firms around them. On the contrary, the interaction between performance hazard and family involvement is significant (Table 2, Model 7). Again, we have plotted this interaction to analyse more in depth this effect (Figure 2). In the case of low values of performance hazard, the higher the number of family employees, the lower firms diversify, whereas the opposite occurs for the case of high performance hazard. In this case, firms perceive the risk and the more family members involve in the business the more firms diversify (see Figure 2). 


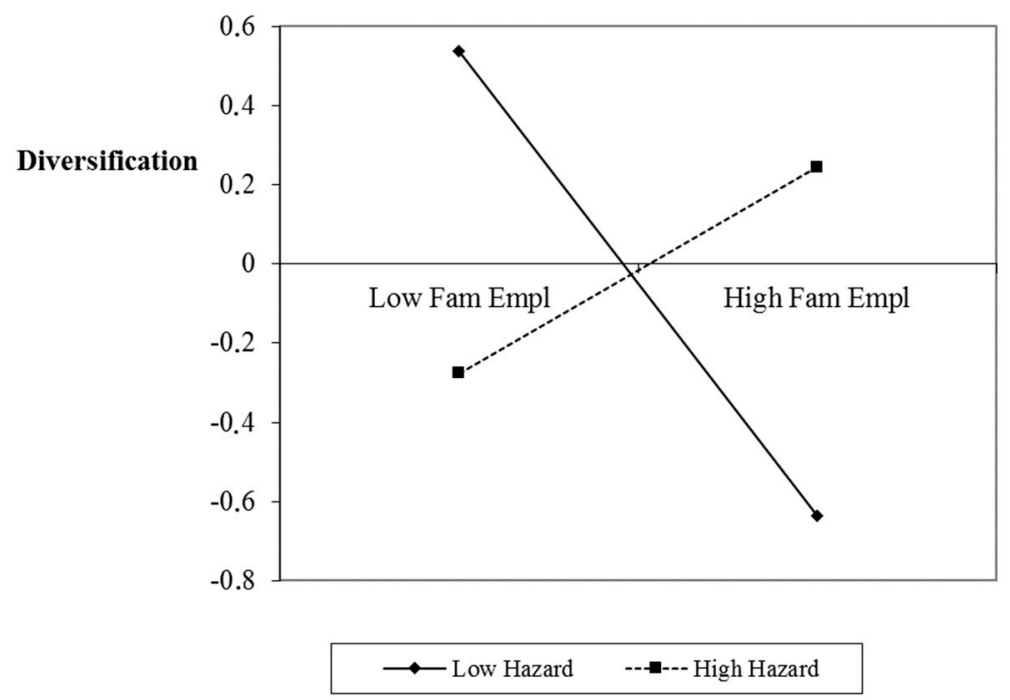

Figure 2. Interaction effect performance hazard-family employees.

The Hosmer-Lemeshow tests to check for the global significance of each of the models were significant, suggesting that all the models are globally significant. Logistic regression does not have an equivalent to the R-squared as can be found in OLS regression. Hence, we had to calculate a pseudo $R$-squared. We used the most common one, which was suggested by [58], known as the "likelihood ratio index". It consists on comparing a model without any predictor to a model including all predictors. Therefore, McFadden index [58] is defined as one minus the ratio of the log-likelihood with intercepts only, and the log-likelihood with all predictors (pseudo $R^{2}=1-$ (restricted log-likelihood/log-likelihood with predictors)). While these values must be used with care, they can provide an idea of the goodness of fit of the model. The pseudo R squares, together with the Bayes Information Criteria (BIC) for our models have been shown in Table 2.

\section{Discussion}

While literature about risk attitudes and diversification behaviour of family firms are not clear and conflicting studies can be found in the literature $[10,59,60]$, in this paper we have shed a light for the case of small family firms, trying to fill the gap that exists in the literature with this regard. As some authors have noted, agency costs and risk attitudes highly depend on the firms' context and sector $[5,61]$. In this work, we have examined the effects that factors such as risk, family involvement, family-related managers or family-employees exert on diversification decisions. Our results corroborated the idea that small family firms are more risk-adverse when compared to their counterpart non-family firms (Hypothesis 1). Among other reasons, we have argued that diversification often carry out the need to hire outsiders with knowledge on the new activity, the reluctance of family members to accept outsider's opinions, keeping the SEW, the fear to lose autonomy and control, etc.

In the context of small family firms, our arguments conflict with the traditional view of risk attitude in Agency theory for bigger firms [5,6], supporting the hypothesis that principals are risk-adverse as their patrimony highly depends on their family firm, in contrast to the diversified portfolio of the shareholders of big firms. On the contrary, agents are more prone to risk, as their behaviour is protected by family ties. Therefore, when we deepened in the analysis, results revealed that agency problems are not totally suppressed in the case of family firms. However, our results suggest that the attitude towards risk of the principal and the agent is the same and that family managers make these attitudes closer with respect to risk taking. Family-managers have the same attitude towards risk than owners. This result contradicts our Hypothesis 2 and other recent studies in the literature. 
For example, Gomez-Mejia et al. [5] noted the agent's attitude towards risk in the case of family firms was different. Therefore, family members may reduce the agency problems (as maintained by [15]).

Furthermore, in this paper, we have given one step forward with respect to the family role by splitting the family involvement into the effect that exert not only the number of generations in the family business but also family employment. We argue that, in small family firms where family ownership is very concentrated, the amount of family employees may play a crucial role in the decisions taken. This is due to two key reasons. On the one hand, there is an evident economic reason: in the case the entrepreneurial activity fails, the higher is the family employment, the higher the number of members of the same family that will be affected. On the other hand, as suggested by [13], the higher the family role, the higher the socioemotional wealth. Following the same logic, the higher the family employment, the higher the SEW in the family business. Again, in the case of risk, there is more to lose.

We have also offer a new perspective on the effect of family role in terms of the number of generations in the family business, offering a different view to the one suggested by the literature which is generally set in the context of larger firms. The literature suggests that the family involvement is highest for the first generations and it becomes lower in subsequent generations. We argue that if family firms do not evolve into larger firms, the family's attachment to the business increases with the number of generations, as descendants feel they need to keep the business and the SEW that was kept over for generations. This is a new perspective as the identification family-business is lost when firms grow larger.

Following [12], we have considered the effect that the systematic risk (epsilon), unsystematic risk (beta) and performance hazard exert on diversification behaviour. We have also analysed the moderating effect that the family role may take. From our results, it seems that small family firms are not very keen on diversification activities while their revenues are stable. However, in the case of performance hazard or when the variability of their revenues becomes high, they feel they need to protect their family patrimony and their socioemotional wealth, which leads them to diversify their activities to avoid risk. Our empirical evidence shows that this feeling and diversification becomes stronger the higher the family involvement in the business, in terms of family employees, as they need to protect the patrimony of several family members. Interestingly, it seems that they need to see their revenues unstable or decreasing to take the decision to diversify but their decision making is not affected by the variability of the sector or the firms around them (the systematic risk).

Finally, we think we have provided some insights that could be useful in the knowledge of the fishing sector, where the number of studies dedicated to risk attitudes or organizational aspects is very scarce. These behavioural models could be taken into account together with biological models of stock dynamics for a better understanding of fleet dynamics [62]. A deep review of fleets dynamics can be found in [63] but the authors do not refer finding any previous studies that includes how the family character of many family firms may drive their behaviour when compared to their counterpart nonfamily firms. Among the studies reviewed, Smith and Wilen [17] analysed risk in an American fishery. They considered two dimensions on risk: physical and financial risk. In our case, both types of risk were associated to the same fishery (the alternative fishery) and, consequently, we could not distinguish them. Pascoe et al. [55] analysed the exit decisions and found that satisfaction with fishing of the challenge of fishing was key on exit decisions whereas other economic variables were not significant. On the other hand, we have extended these and other previous works in the fishing sector by including the effect of other organizational variables such as separation of ownership and management, family employees or family related managers. This study would not only help to a better understanding of the owner's and manager's decisions but it could also have strong policy implications. In particular, our empirical application could provide managers some valuable information that could help policy makers to predict fishers behaviour and could also help to establish fishery regulations. In the case of fleets that have the option of alternating with another fishery, similar models could be used when fishery managers are interested in encouraging fishers to operate in the alternative 
fishery to diminish the pressure exerted on the traditional fishery (or the other way round). Depending on which of these two fisheries is closer to sustainable levels, it could be interesting to encourage fishermen to operate in one or another. This is a relevant issue as overcapacity in fisheries is widely accepted as a major problem at the international level [55]. A deep knowledge of the potential reactions of the fleet at the individual level could provide interesting policy implications and could also provide a hint for a better management design. Therefore, the knowledge of the different organizational aspects of the individual firms in a fleet would be of help for fisheries managers at a local, national and even international level as is the case of shared fisheries.

Altogether, our results can be of help to understand the decision making process under risk in family firms, where the balance between preserving SEW and daring to diversify or initiate entrepreneurial activities is difficult to maintain. This is particularly interesting as family firms are assumed to more likely act in the interests of their stakeholders [64] and in a more sustainable way $[18,64]$. Our paper also helps to understanding the agency relationships within small firms and how some moderator variables affect diversification decisions, which could be part of the reasons of their success or failure. However, there is still a big horizon for research.

Among others, one limitation of our study is that we have only considered the fishing sector and a measure of diversification that is very specific to this industry. A future line of research should aim at extending this analysis to other industries and using other measures of diversification to confirm the generalization of the hypotheses presented here to other contexts. Furthermore, while the arguments provided in this paper apply to small family firms, they could differ in many aspects to large family firms. Consequently, the results of the studies in one of these contexts cannot be generalized to other contexts.

\section{Conclusions}

Our paper makes several relevant contributions to the Business Management literature. First, we contribute to the literature by analysing the different diversification attitudes in a family firm context. This is an interesting issue, as some authors [13] suggest that the attitude of family firms is the opposed to that of non-family firms and that it is confronted with the traditional views for bigger firms. Our results partly support the ideas appointed by some authors $[5,6,13]$ and are on the same line than those of McConaughy et al. [65].

With this regard, another contribution to the management literature is that we extend some previous works, by addressing the effect that the family involvement exerts on diversification strategies. We analyse the concept of family involvement, and look for the right definition in the case of small family firms. Most papers analysing the effect of family involvement on strategic behaviour and risk attitudes measure family involvement as the amount of shares (or the percentage of stock) the family owns [26,35]. According to these scholars, when members of the same family are large shareholders, risk preferences change. However, in small family firms, the ownership structure is often very simple and, commonly, ownership is concentrated in a few hands [35] or even in just one single owner. Therefore, in this paper, we argue that family involvement in these small firms would be better analysed by the number of family employees working in the family business. Consequently, considering that we are dealing with small firms, we have considered family involvement not only in terms of the family stage with respect to the number of generations in the business as is the case in most literature $[13,37,38]$ but we have also considered the number of family employees working in the family business. We argue that the effect of having family employees in small firms may represent a substantial percentage of the employment and it becomes a relevant issue concerning the family role. Therefore, we maintain that, in the context of small firms, the family attachment to the organization is related to both variables. The issue of family role in terms of family employment was raised up by [39]. These scholars support a continuum definition of family business rather than a bi-polar treatment of family firm [59]. These authors maintain that the number of family members involved in the business affects directly its family character. 
Another contribution is related to the effect of family tenure on diversification activities. We offer a new perspective on the influence of generations over diversification strategies when dealing with small family firms. While family firm literature has traditionally assumed that, in the first generations, family's attachment is highest and present higher risk aversion which becomes lower in subsequent generations, we argue that in small firms the reverse occurs. In a way, our arguments are in line with some previous studies [25]. We maintain that the traditional assumption on the effect of family generations is valid for those family firms that evolve into larger firms.

While the owner's responsibility over non-managerial family employees may affect his decision-making, we have also analysed the case where the manager is family related. The results support the ideas of [5] and contradict the traditional agency theory, which is more focused on larger firms.

Our study supports the hypotheses of [12] on the influence of systematic (beta risk) and unsystematic (epsilon) risks on decision-making. We have gone further by analysing the moderating effect that the family role (in our case, measured as a continuous variable in terms of family employment) exerts in the relationship between performance hazard and diversification in family firms. We maintain that the arguments in favour and against family firms being more prone to diversify can be combined by suggesting that while family firms tend to preserve SEW when they perceive environmental hazard or see themselves in risky environments, they prefer to diversify to survive and to be sustainable over time. We conclude that, while family firms are risk averse and are reluctant to diversify, if they feel their performance is menaced with increasing variability and if their profitability decreases over time, they see diversification as an escape route to become sustainable over time or simply to survive. According to this, family firms should not be seen as risk averse, but loss-averse [11] as they would be more sensitive to losing wealth (and in particular SEW) than to increasing wealth. We also argue that this reasoning is particularly strong if family involvement is high as the work and the patrimony of several family members may be at risk. Interestingly, while firms' decisions are affected by the risk they perceived in their firms and moderated by family involvement, they are not affected by the variability in the firms around them.

Finally, our work also contributes to the existing literature on the fishing industry. We applied our study to firms in the fishing sector, which is very important for the development of some local communities but which has hardly been studied by management researchers [15]. Many authors maintain that a key issue to achieve sustainable management of fish resources is to understand fishers' behaviours and fleet dynamics [63] and have stressed that fisheries should be managed according to biophysical and socioeconomic elements [62]. Furthermore, our study tries to answer the call of [55] that reckon that while economic influence is important, a more global examination of the factors driving fisher's behaviour is needed. A key contribution of this study is that it may help to understand the diversification decisions in the fishing sector. Many fisheries seem to be over exploited and in constant crisis, reason for which, understanding the mechanisms of why and when small fishing firms take the option to operate in alternative fisheries is crucial because a switch to alternative fisheries can be of help for the recovery of overexploited fisheries. Predicting who may leave a fishery or who may alternate a specific fishery with another seasonal fishery is an important consideration when designing capacity reduction programs to enhance both ecological and economic sustainability [55].

Acknowledgments: This work has been financed by the Ministry of Economy and Competence of Spain through Project ECO2016-75047-P.

Conflicts of Interest: The author declares no conflict of interest. The founding sponsors had no role in the design of the study; in the collection, analyses, or interpretation of data; in the writing of the manuscript, and in the decision to publish the results.

\section{References}

1. Stern, I.; Henderson, A.D. Within-business diversification in technology-intensive industries. Strateg. Manag. J. 2004, 25, 487-505. [CrossRef] 
2. Kellermanns, F.W.; Eddleston, K.A. Feuding Families: When Conflict Does a Family Firm Good. Entrep. Theory Pract. 2004, 18, 209-228.

3. Arrow, K.J. Aspects of the Theory of Risk-Bearing; Yrjö Jahnssonin Säätiö: Finland, Helsinski, 1965. Available online: http:/ / www.scirp.org/\%28S\%28351jmbntvnsjt1aadkposzje\%29\%29/reference/ReferencesPapers. aspx?ReferenceID=1641644 (accessed on 14 November 2017).

4. Gedajlovic, M.H.; William, S. Crossing the Threshold from Founder Management to Professional Management: A Governance Perspective. J. Manag. Stud. 2004, 41, 899-912. [CrossRef]

5. Gomez-Mejia, L.R.; Nuñez-Nickel, M.; Gutierrez, I. The Role of Family Ties in Agency Contracts. Acad. Manag. J. 2001, 44, 81-95. [CrossRef]

6. Naldi, L.; Nordqvist, M.; Sjöberg, K.; Wiklund, J. Entrepreneurial Orientation, Risk Taking, and Performance in Family Firms. Fam. Bus. Rev. 2007, 20, 33-47. [CrossRef]

7. Sniezek, J.; Henry, R. Accuracy and confidence in group judgement. Organ. Behav. Hum. Decis. Process. 1989, 43, 1-28. [CrossRef]

8. Villalonga, B.; Amit, R. How do family ownership, control and management affect firm value? J. Financ. Econ. 2006, 80, 385-417. [CrossRef]

9. Lim, E.N.K.; Lubatkin, M.H.; Wiseman, R.M. A family firm variant of the behavioral agency theory. Strateg. Entrep. J. 2010, 4, 197-211. [CrossRef]

10. Miller, D.; Le Breton-Miller, I.; Lester, R.H. Family and Lone Founder Ownership and Strategic Behaviour: Social Context, Identity, and Institutional Logics. J. Manag. Stud. 2011, 48, 1-25. [CrossRef]

11. Carney, M.; Van Essen, M.; Gedajlovic, E.R.; Heugens, P.P.M.A.R. What do we know about private family firms? A meta-analytical review. Entrep. Theory Pract. 2015, 39, 513-544. [CrossRef]

12. Gomez-Mejia, L.R.; Makri, M.; Kintana, M.L. Diversification decisions in family-controlled firms. J. Manag. Stud. 2010, 47, 223-252. [CrossRef]

13. Gómez-Mejía, L.R.; Haynes, K.T.; Núñez-Nickel, M.; Jacobson, K.J.; Moyano-Fuentes, J. Socioemotional wealth and business risks in family-controlled firms: Evidence from Spanish olive oil mills. Adm. Sci. $Q$. 2007, 52, 106-137. [CrossRef]

14. Kellermanns, F.W.; Eddleston, K.A.; Barnett, T.; Pearson, A. An exploratory study of family member characteristics and involvement: Effects on entrepreneurial behavior in the family firm. Fam. Bus. Rev. 2008, 21, 1-14. [CrossRef]

15. Herrero, I. Agency Costs, Family Ties, and Firm Efficiency. J. Manag. 2011, 37, 887-904. [CrossRef]

16. Hilborn, R.; Maguire, J.-J.; Parma, A.M.; Rosenberg, A.A. The Precautionary Approach and risk management: Can they increase the probability of successes in fishery management? Can. J. Fish. Aquat. Sci. 2001, 58, 99-107. [CrossRef]

17. Smith, M.D.; Wilen, J.E. Heterogeneous and correlated risk preferences in commercial fishermen: The perfect storm dilemma. J. Risk Uncertain. 2005, 31, 53-71. [CrossRef]

18. Caputo, F.; Veltri, S.; Venturelli, A. Sustainability Strategy and Management Control Systems in Family Firms. Evidence from a Case Study. Sustainability 2017, 9, 977. [CrossRef]

19. Anderson, R.C.; Reeb, D.M. Founding-family ownership and firm performance. J. Financ. 2003, 58, 1301-1327. [CrossRef]

20. Schulze, W.S.; Lubatkin, M.H.; Relationships, A.; Dino, R.N.; Buchholtz, A.K. Agency Relationships in Family Firms: Theory and Evidence. Organ. Sci. 2001, 12, 99-116. [CrossRef]

21. Naldi, L.; Chirico, F.; Kellermanns, F.W.; Campopiano, G. All in the Family? An Exploratory Study of Family Member Advisors and Firm Performance. Fam. Bus. Rev. 2015, 28, 227-242. [CrossRef]

22. Goel, S.; Jones, R.J. Entrepreneurial Exploration and Exploitation in Family Business. Fam. Bus. Rev. 2016, 29, 94-120. [CrossRef]

23. Gray, C. Entrepreneurship, resistance to change and growth in small firms. J. Small Bus. Enterp. Dev. 2002, 9, 61-72. [CrossRef]

24. Daily, C.M.; Dollinger, M.J. Family Firms Are Different. Rev. Bus. 1991, 13, 3.

25. Claver, E.; Rienda, L.; Quer, D. Family firms' risk perception: Empirical evidence on the internationalization process. J. Small Bus. Enterp. Dev. 2008, 15, 457-471. [CrossRef]

26. Miller, D.; Breton-Miller, I.L.; Lester, R.H. Family ownership and acquisition behavior in publicly-traded companies. Strateg. Manag. J. 2010, 31, 201-223. [CrossRef] 
27. Zahra, S.A. Harvesting family firms' organizational social capital: A relational perspective. J. Manag. Stud. 2010, 47, 345-366. [CrossRef]

28. Cruz, C.C.; Gómez-Mejia, L.R.; Becerra, M. Perceptions of benevolence and the design of agency contracts: CEO-TMT relationships in family firms. Acad. Manag. J. 2010, 53, 69-89. [CrossRef]

29. Galve Górriz, C.; Salas Fumás, V. Ownership Structure and Firm Performance: Some Empirical Evidence from Spain. Manag. Decis. Econ. 1996, 17, 575-586. [CrossRef]

30. Wiseman, R.M.; Gomez-mejia, L.R. A Behavioral Agency Model of Managerial Risk Taking. Acad. Manag. Rev. 1998, 23, 133-153.

31. Le Breton-Miller, I.; Miller, D. Commentary: Family firms and the advantage of multitemporality. Entrep. Theory Pract. 2011, 35, 1171-1177. [CrossRef]

32. Olson, P.D.; Zuiker, V.S.; Danes, S.M.; Stafford, K.; Heck, R.K.Z.; Duncan, K.A. The impact of the family and the business on family business sustainability. J. Bus. Ventur. 2003, 18, 639-666. [CrossRef]

33. Cruz, C.; Justo, R.; De Castro, J.O. Does family employment enhance MSEs performance?. Integrating socioemotional wealth and family embeddedness perspectives. J. Bus. Ventur. 2012, 27, 62-76. [CrossRef]

34. Berrone, P.; Cruz, C.; Gomez-Mejia, L.R. Socioemotional Wealth in Family Firms: Theoretical Dimensions, Assessment Approaches, and Agenda for Future Research. Fam. Bus. Rev. 2012, 25, 258-279. [CrossRef]

35. Schulze, W.S.; Lubatkin, M.H.; Dino, R.N. Altruism, agency, and the competitiveness of family firms. Manag. Decis. Econ. 2002, 23, 247-259. [CrossRef]

36. Dyer, W.G.; Nenque, E.; Hill, E.J. Toward a theory of family capital and entrepreneurship: Antecedents and outcomes. J. Small Bus. Manag. 2014, 52, 266-285. [CrossRef]

37. Schulze, W.S.; Lubatkin, M.H.; Dino, R.N. Exploring the agency consequences of ownership dispersion among the directors of private family firms. Acad. Manag. J. 2003, 46, 179-194. [CrossRef]

38. Chua, J.H.; Chrisman, J.; Sharma, P. Succession and nonsuccession concerns of family firms and agency relationship with nonfamily managers. Fam. Bus. Rev. 2003, 16, 89-107. [CrossRef]

39. Astrachan, J.H.; Klein, S.B.; Smyrnios, K.X. The F-PEC Scale of Family Influence: A Proposal for Solving the Family Business Definition Problem. Fam. Bus. Rev. 2002, 15, 45-58. [CrossRef]

40. Sharma, P.; Chrisman, J.J.; Chua, J. Strategic Management of the Family Business: Past Research and Future Challenges. Fam. Bus. Rev. 1997, 10, 1-35. [CrossRef]

41. Arregle, J.L.; Hitt, M.A.; Sirmon, D.G.; Very, P. The development of organizational social capital: Attributes of family firms. J. Manag. Stud. 2007, 44, 73-95. [CrossRef]

42. Brannon, D.L. A Socioemotional Wealth Perspective in Small Family Firms. Acad. Entrep. J. 2016, 22, 51-65.

43. Barney, J.B.; Ouchi, W. Organizational Economics; Jossey Bass: San Francisco, CA, USA, 1986.

44. Eisenhardt, K.M. Agency theory: An assessment and review. Acad. Manag. Rev. 1989, 14, 57-74.

45. Schulze, W.S.; Gedajlovic, E.R. Whither Family Business? J. Manag. Stud. 2010, 47, 191-204. [CrossRef]

46. Zahra, S.A. Entrepreneurial risk taking in family firms. Fam. Bus. Rev. 2005, 18, 23-40. [CrossRef]

47. Miller, J.S.; Wiseman, R.M.; Gomez-Mejia, L.R. The fit between CEO compensation design and firm risk. Acad. Manag. J. 2002, 45, 745-756. [CrossRef]

48. Miller, D.; Le Breton-Miller, I.; Lester, R.H.; Cannella, A.A. Are family firms really superior performers? J. Corp. Financ. 2007, 13, 829-858. [CrossRef]

49. March, J.G.; Shapira, Z. Variable risk preferences and the focus of attention. Psychol. Rev. 1992, 99, $172-183$. [CrossRef]

50. Miller, K.D.; Chen, W.R. Variable organizational risk preferences: Tests of the March-Shapira model. Acad. Manag. J. 2004, 47, 105-115. [CrossRef]

51. Kasperski, S.; Holland, D.S. Income diversification and risk for fishermen. Proc. Natl. Acad. Sci. USA 2013, 110, 2076-2081. [CrossRef] [PubMed]

52. Crowder, L.B.; Murawski, S.A.; Crowder, B.L.B.; Murawski, S.A. Fisheries Bycatch: Implications for Management Fisheries Bycatch: Implications for Management. Fisheries 1998, 23, 8-17. [CrossRef]

53. Smith, C.L.; McKelvey, R. Specialist and Generalist: Roles for Coping with Variability. N. Am. J. Fish. Manag. 1986, 6, 88-99. [CrossRef]

54. Beehr, T.A.; Drexler, J.A.; Faulkner, S. Working in small family business: Empirical comparisons to nonfamily business. J. Organ. Behav. 1997, 18, 297-312. [CrossRef]

55. Pascoe, S.; Cannard, T.; Jebreen, E.; Dichmont, C.M.; Schirmer, J. Satisfaction with fishing and the desire to leave. Ambio 2015, 44, 401-411. [CrossRef] [PubMed] 
56. Hilborn, R. Fleet dynamics and individual variation: Why some people catch more fish than others. Can. J. Fish. Aquat. Sci. 1985, 42, 2-13. [CrossRef]

57. Hilborn, R.; Walters, C.J. A general model for simulation of stock and fleet dynamics in spatially heterogeneous fisheries. Can. J. Fish. Aquat. Sci. 1987, 44, 1366-1370. [CrossRef]

58. Mc Fadden, D. Conditional logit analysis of qualitative choice behavior. In Frontiers in Econometrics; Zarembka, P., Ed.; Academic Press: New York, NY, USA, 1973.

59. Sharma, P. An Overview of the Field of Family Business Studies: Current Status and Directions for the Future. Fam. Bus. Rev. 2004, 17, 1-36. [CrossRef]

60. Schulze, W.S.; Lubatkin, M.H.; Dino, R.N. Toward a theory of agency and altruism in family firms. J. Bus. Ventur. 2003, 18, 473-490. [CrossRef]

61. Dyer, G.W. Examining the "Family Effect" on Firm Performance. Fam. Bus. Rev. 2006, 19, 253-273. [CrossRef]

62. Dudley, R.G. A Basis for Understanding Fishery Management Dynamics. Syst. Dyn. Rev. 2008, $24,1-29$. [CrossRef]

63. Van Putten, I.E.; Kulmala, S.; Thébaud, O.; Dowling, N.; Hamon, K.G.; Hutton, T.; Pascoe, S. Theories and behavioural drivers underlying fleet dynamics models. Fish Fish. 2012, 13, 216-235. [CrossRef]

64. Hernández-Perlines, F.; Rung-Hoch, N. Sustainable entrepreneurial orientation in family firms. Sustainability 2017, 9, 1212. [CrossRef]

65. McConaughy, D.L.; Matthews, C.H.; Fialko, A.S. Founding family controlled firms: Performance, risk, and value. J. Small Bus. Manag. 2001, 39, 31-49. [CrossRef]

(C) 2017 by the author. Licensee MDPI, Basel, Switzerland. This article is an open access article distributed under the terms and conditions of the Creative Commons Attribution (CC BY) license (http://creativecommons.org/licenses/by/4.0/). 